\title{
DAMPAK SISTEM ERP TERKAIT RELEVANSI INFORMASI AKUNTANSI DAN KINERJA PERUSAHAAN : PERUSAHAAN ADOPSI ERP DAN TIDAK ADOPSI ERP
}

\author{
Dwi May Adi Indra Luciana \\ lucianamayadi@gmail.com \\ Universitas Airlangga, Surabaya \\ Noorlailie Soewarno \\ noorlailie-s@ feb.unair.ac.id \\ Universitas Airlangga, Surabaya \\ Isnalita \\ isnalitas@feb.unair.ac.id \\ Universitas Airlangga, Surabaya
}

\begin{abstract}
Abstrak
Sistem ERP (Enterprise Resource Planning) dianggap memberikan keuntungan bagi perusahaan. Sistem ERP juga membantu memberikan informasi akuntansi yang berguna bagi pengambilan keputusan. Penelitian ini bertujuan untuk mengetahui dampak sistem ERP pada relevansi informasi akuntansi dan kinerja perusahaan pada perusahaan yang mengadopsi ERP dan perusahaan yang tidak mengadopsi ERP. Pada penelitian ini relevansi informasi akuntansi diuji dengan tiga variabel yaitu predictive value, timeliness dan feedback value. Hasil analisis ini diperoleh dari kuesioner yang telah dibagikan kepada 75 perusahaan, terdiri dari 40 perusahaan yang mengadopsi sistem ERP dan 35 perusahaan yang tidak adopsi sistem ERP, sampel yang diperoleh masing-masing hanya 30 perusahaan sehingga terdapat 60 perusahaan yang diteliti. Hipotesis dalam penelitian ini diuji menggunakan analisis nonparametrik Mann Whitney dengan SPSS untuk mencari perbedaan dampak dari dua jenis perusahaan. Analisis ini membuktikan bahwa sistem ERP berdampak terhadap relevansi informasi akuntansi yang terdiri dari tiga variabel dan kinerja perusahaan pada perusahaan yang mengadopsi sistem ERP.
\end{abstract}

Keywords : ERP, Value Relevance, Firm Performance

\section{Pendahuluan}

Teknologi mengalami perkembangan yang sangat cepat, segala sesuatu akan semakin mudah dengan bantuan teknologi. Sistem ERP merupakan salah satu dari sekian banyak teknologi yang memudahkan dalam pengambilan keputusan serta membantu kinerja perusahaan. Sistem ini dapat membantu perusahaan dalam mengelola informasi 
internal dan eksternal menjadi informasi akuntansi yang berkualitas untuk pengambilan keputusan. Implementasi ERP dalam sebuah perusahaan membutuhkan konfigurasi yang cukup besar, namun tidak perlu melakukan pemograman ulang dan teknologi yang digunakan harus sesuai dengan persyaratan (Locke dan Lowe, 2007).

Kualitas informasi merupakan bagian yang sangat penting bagi perusahaan yang berguna untuk pengambilan keputusan. Perkembangan teknologi pada saat ini menciptakan persaingan pasar yang kompetitif sehingga perusahaan bersaing untuk mencari cara agar bisa mengolah informasi degan cepat dan efektif. HassabElnaby dkk dalam Attayah dan Ibrahim (2014) menyatakan bahwa bisnis global yang kompetitif berusaha untuk bertahan dalam persaingan dengan menggunakan sistem informasi. Penggunaan sistem ERP sangat berguna untuk memperbaiki pengambilan keputusan dan perusahaan dapat menyimpan informasi yang penting. Kualitas informasi dipengaruhi oleh strategi dalam mendapatkan informasi dan pengolahan informasi, hal ini dapat meningkatkan kinerja perusahaan (Ferdows dan Meyer, 1990).

Sistem ERP bukanlah sistem yang sempurna, sistem tersebut juga mengalami kegagalan namun banyak perusahaan yang tidak memperdulikan hal tersebut, mereka tetap berinvestasi pada sistem ERP (Ehie dan Madsen, 2005). Perusahaan mengadopsi sistem ERP berharap mendapatkan keuntungan finansial dan non-finansial.

Galy dan Mary (2014) berpendapat bahwa sistem ERP memerlukan koordinasi teknologi dalam perusahaan, sehingga implementasi sistem ERP pada perusahaan berhasil dan perusahaan akan memperoleh manfaat yang besar. Penerapan sistem ERP pada perusahaan akan sangat membantu, sehingga laporan keuangan akan lebih terkontrol dengan baik dan akan menarik minat investor untuk menanamkan modal pada perusahaan.

Penerapan ERP pada awalnya akan membutuhkan biaya yang cukup besar, hal inilah yang membuat beberapa perusahaan harus berpikir dua kali dalam implementasi ERP. Namun manfaat dalam jangka panjang akan sangat besar, keuntungan yang di dapat lebih besar daripada biaya yang dikeluarkan pada saat implementasi. Pengeluaran perusahaan dapat diminimalisir dengan implementasi sistem ERP.

Implementasi ERP merupakan suatu proses yang cukup luas dan menghabiskan biaya yang cukup besar, hal ini dikarenakan sistem ERP mengelola tugas yang komplek. Sistem ini melibatkan pemangku kepentingan seperti manajer, staf operasional dan pengetahuan yang cukup luas sepanjang implementasi (Sevenpri, 2012).

Penelitian yang dilakukan Behesthti dan Behesthti (2010) pengeluaran ERP meliputi pembelian perangkat keras maupun lunak, jaringan dan biaya konsultasi. Semakin besar perusahaan, biaya yang dibutuhkan untuk implementasi ERP akan semakin banyak. Implementasi sistem ERP membutuhkan waktu yang cukup lama, biaya yang besar dan sumber daya yang harus terlatih sehingga implementasi ERP menimbulkan resiko untuk perusahaan (Hitt dan Brynjolfsson, 1996). 
Penelitian ini meneliti perbedaan antara perusahaan yang telah mengadopsi ERP dan perusahaan yang tidak mengadopsi ERP dilihat dari value relevance meliputi predictive value, timelines, feedback value dan kinerja perusahaan.

\section{Landasan Teori}

ERP merupakan teknologi berupa perangkat lunak yang membantu organisasi dalam mengelola bisnis dengan efektif dan efisien (Nah dan Lau dalam Attayah dan Ibrahim, 2014). Sistem dapat membantu kinerja perusahaan sehingga mereka dapat meminimalkan waktu serta biaya yang dikeluarkan. Implementasi awal ERP membutuhkan pelatihan dan waktu cukup lama, namun perusahaan akan memperoleh manfaat yang begitu besar.

Teknologi yang inovatif menurut Drucker dan Huber dalam Hunton, et al (2003) adalah teknologi yang dapat membantu proses bisnis organisasi, seperti:

1. Informasi yang lebih akurat, efektif, efisien dan memberikan informasi eksternal dan internal yang lengkap.

2. Mengidentifikasi masalah dan peluang dengan akurat dan efektif

3. SDM yang dibutuhkan lebih sedikit untuk mengelola informasi

4. Organisasi yang terlibat dalam pengambilan keputusan lebih sedikit

5. Pengambilan keputusan lebih cepat, sehingga masalah lebih cepat diatasi.

ERP merupakan inovasi teknologi yang memudahkan organisasi dalam mengatasi masalah, hal ini dikarenakan dengan menggunakan ERP mereka lebih cepat dalam pengambilan keputusan serta memiliki biaya yang lebih sedikit karena pekerja dan organisasi yang terlibat lebih sedikit. Penelitian yang dilakukan Gatticker dan Goodhue (2005) menyatakan bahwa sistem ERP memiliki dampak yang signifikan apabila produk yang digunakan untuk produksi dan distribusi dioptimalkan.

ERP merupakan sebagai sistem yang berguna untuk mengintegrasikan sistem informasi yang berguna bagi infrastruktur bisnis. Kebanyakan sistem tidak dapat menilai kinerja perusahaan namun ERP dapat memberikan pengukuran kinerja, hal ini sangat berpengaruh pada pengambilan keputusan (Shen, et al. 2015).

Lorca dan Andrés dalam Kocaoglu dan Zafer (2015) menyatakan bahwa sistem ERP merupakan sistem standar yang dapat mengatasi semua parameter yang dibutuhkan secara terstruktur. ERP juga merupakan sistem yang sangat inovatif dan dapat melengkapi sistem perusahaan yang lain, ERP juga memiliki kemampuan untuk memberikan informasi pada manajemen. Dechow dan Mouritsen (2005) mengidentifikasi dalam penelitiannya bahwa output dari ERP akan berbeda-beda sesuai dengan tujuan dari pengguna.

Nilai relevansi berkaitan dengan pengambilan keputusan hal ini sesuai dengan pendapat Kieso (2011) bahwa informasi akuntansi akan lebih bermanfaat bagi pengambilan keputusan, namun mereka juga harus mempertimbangkan waktu dan biaya. Pengambilan keputusan yang baik harus mempertimbangkan nilai masa lalu dan dapat memprediksikan masa depan. Dalam penelitian yang dilakukan Attayah dan Ibrahim 
(2014) berpendapat bahwa informasi akuntansi yang relevan adalah informasi yang berguna untuk pengambilan keputusan.

Kinerja keuangan dari perusahaan yang mengadopsi ERP menurut Eliashberg dan Chatterjee dalam Hunton, et al (2003) tidak mengalami peningkatan namun memiliki perbedaan dengan perusahaan yang tidak mengadopsi ERP. Tujuan dari ERP adalah mengintegrasikan teknologi, sumber daya guna memenuhi kebutuhan pelanggan dan meningkatkan kinerja operasional peusahaan. Manfaat dari adopsi sistem ERP menurut Chand et al. (2005) mengurangi biaya operasional dan dapat meningkatkan keuntungan perusahaan.

Wheatly dalam Alcivar (2016) menyebutkan masalah yang dapat mempengaruhi gagalnya penerapan ERP, yaitu :

1. Pelatihan karyawan tentang sistem yang gagal

2. Dampak pelatihan bagi perusahaan terutama masalah biaya

3. Negosiasi yang sulit antara perusahaan dan vendor pelatihan ERP

4. Implementasi dilakukan dengan cepat sehingga pelatihan berlangsung dengan singkat

5. Karyawan tidak memiliki pengetahuan tentang konsep sistem ERP.

Keberhasilan sistem ERP dipengaruhi oleh pengetahuan pengguna dalam proses pemahaman sistem dan penerapan sistem dalam perusahaan, sehingga hal ini akan menimbulkan integrasi sistem dengan strategi manajemen sehingga penggunaan sistem akan lebih optimal (Albers dan Trinidad, 2006).

Penelitian May et al. (2013) sistem ERP memiliki dampak yang signifikan terhadap peningkatan produk perusahaan manufaktur karena sitem ERP melihat bagaimana produk diproduksi dan sumbr daya yang dioptimalkan. Peningkatan produk dipengaruhi tiga factor yaitu:

1. Manajer harus memastikan bahwa sistem yang digunakan mendukung pengembangan produk tersebut.

2. Manajer juga harus memastikan sistem yang di adopsi mendukung pertumbuhan produk tersebut

3. Manajer harus memastikan adanya kesempatan untuk mengidentifikasi produk tersebut.

Ketidakpastian lingkungan dapat menyulitkan manajer dalam mengambil keputusan, hal ini karena lingkungan yang tidak pasti informasi ang dibutuhkan akan cenderung berkurang. Berkurangnya suatu informasi disebabkan karena harus adanya koordinasi kegiatan (Madapusi dan D'Souza, 2012).

Implementasi sistem ERP akan optimal apabila penggunaannya dilakukan secara maksimal, menurut Scott dan Vessey (2000) dalam memaksimalkan sistem ada beberapa hal yang harus diperhatikan :

1. Pengguna harus memastikan bahwa sistem ERP mudah digunakan

2. Manajer perlu mempromosikan sistem ERP dalam lingkungan kerja 
3. Pengguna juga harus memastikan bahwa sistem ERP merupakan sistem yang fleksibel

4. Pengguna memastikan informasi dapat digunakan tepat waktu

5. Manajer harus memastikan penggunaan sistem ERP secara kontinyu

Hipotesis yang digunakan dalam penelitian ini adalah :

$H_{1}=$ Ada perbedaan dampak yang signifikan antara perusahaan adopsi dan perusahaan non-adopsi ERP dalam relevansi informasi akuntansi karena penggunaan sistem ERP

\section{Pengaruh ERP terhadap relevansi informasi akuntansi}

Relevansi informasi akuntansi suatu perusahaan merupakan salah satu tolak ukur yang diperhatikan oleh calon investor dan digunakan untuk pengambilan keputusan, sehingga implementasi sistem ERP berdampak bagi perusahaan. Penelitian Attayah dan Ibrahim (2014) menyatakan bahwa sistem ERP memiliki pengaruh yang besar terhadap relevansi informasi akuntansi perusahaan. Sistem ERP memungkinkan perusahaan memiliki masa depan yang lebih baik karena sistem ini dapat memberikan peramalan terkait nilai prediktif sehingga manajer dapat mengambil keputusan secara rasional. Pengolahan informasi yang singkat sehingga pengolahan data lebih banyak dan berpengaruh pada relevansi informasi akuntansi.

$\mathbf{H}_{2}=$ Ada perbedaan dampak yang signifikan antara perusahaan adopsi dan perusahaan non-adopsi ERP dalam kinerja perusahaan karena penggunaan sistem ERP.

\section{Pengaruh ERP terhadap kinerja perusahaan}

Implementasi sistem ERP berdampak pada kinerja perusahaan sesuai dengan penelitian yang dilakukan oleh Hunton, et al. (2003), pada perusahaan adopsi terjadi peningkatan kinerja perusahaan dan hal ini berpengaruh pada keuntungan yang diperoleh perusahaan. Sistem ini membantu pengolahan informasi secara singkat sehingga karyawan akan memperoleh banyak waktu untuk meningkatkan kreativitas.

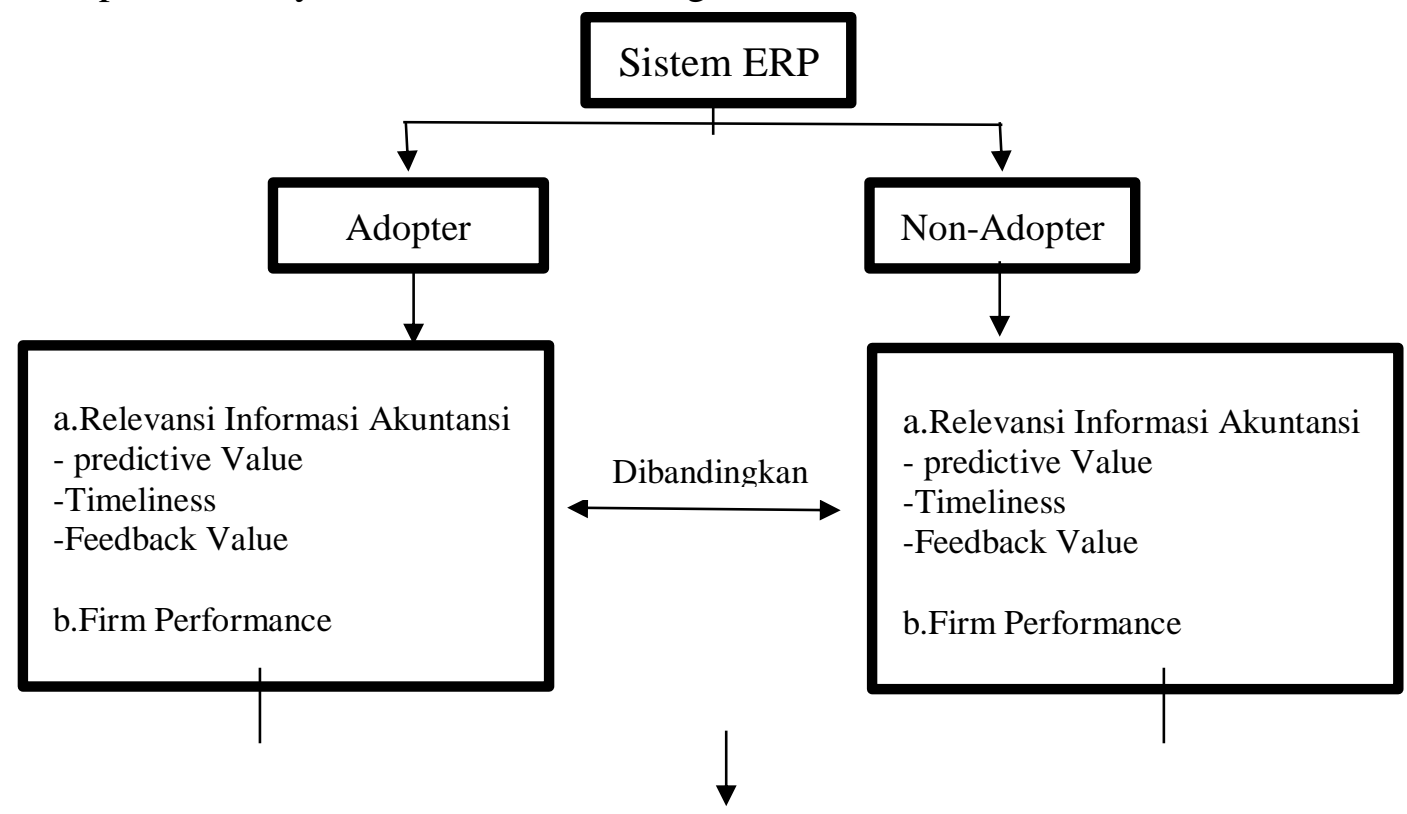


Uji Beda

Figure I : Conceptual Framework

\section{Metode Penelitian}

\section{Sampel dan Pengumpulan Data}

Penelitian ini menggunakan sampel sebanyak 30 perusahaan pada masing-masing kriteria yaitu perusahaan yang adopsi ERP dan perusahaan yang tidak adopsi ERP. Pengumpulan data dilakukan dengan mengirimkan kuesioner melalui e-mail pada tiap perusahaan. Penelitian ini memberikan sampel kepada perusahaan dengan adopsi ERP sebanyak 40 kuesioner dan kuesioner tersebut terjawab sebanyak 30 perusahaan. Penyebaran kuesioner pada perushaan yang tidak adopsi ERP sebanyak 35 perusahaan dan terjawab sebanyak 30 kuesioner.

\section{Instrumen}

Dalam menguji hipotesis, kuesioner terdiri dari pertanyaan-pertanyaan yang berkaitan dengan masing-masing variable yaitu variable predictive value sebanyak empat pertanyaan, timeliness sebayak enam pertanyaan, feedback value sebanyak 5 pertanyaan dan variable terakhir yaitu kinerja perusahaan sebanyak 10 pertanyaan.

\section{Uji hipotesis}

Untuk menguji hipotesis penelitian ini membagi dua sampel yaitu perusahaan adopsi ERP dan perusahaan yang tidak adopsi ERP. Selanjutnya penelitian ini akan menguji perbedaan dari perusahaan adopsi ERP dan perusahaan yang tidak adopsi ERP dengan melakukan uji 6onparametric Mann Whitney pada SPSS.

\section{Pembahasan}

Pengaruh penggunaan sistem ERP terhadap relevansi informasi akuntansi dan kinerja perusahaan, statistic deskriptif terdiri dari mean dan standar deviasi untuk perusahaan yang mengadopsi dan perusahaan yang tidak mengadopsi.

Table 1

Deskripsi Statistik

\begin{tabular}{|c|c|c|c|c|c|}
\hline \multicolumn{6}{|c|}{ Descriptive statistics for all item } \\
\hline \multirow[t]{2}{*}{ No. } & \multirow[t]{2}{*}{ Item } & \multicolumn{2}{|c|}{ Adopter } & \multicolumn{2}{|c|}{ Non Adopter } \\
\hline & & Mean & SD & Mean & $\mathrm{SD}$ \\
\hline 1. & $\begin{array}{l}\text { Predictive Item } \\
\text { Average }\end{array}$ & 18.56 & 1.07 & 11.70 & 2.21 \\
\hline 2. & $\begin{array}{l}\text { Timeliness } \quad \text { Item } \\
\text { Average }\end{array}$ & 25.56 & 2.37 & 18.53 & 4.26 \\
\hline
\end{tabular}


DAMPAK SISTEM ERP TERKAIT RELEVANSI INFORMASI AKUNTANSI DAN KINERJA PERUSAHAAN : PERUSAHAAN ADOPSI ERP DAN TIDAK ADOPSI ERP

\begin{tabular}{|l|l|l|l|l|l|}
\hline 3. & $\begin{array}{l}\text { Feedback Item } \\
\text { Average }\end{array}$ & 19.70 & 2.23 & 16.07 & 1.89 \\
\hline 4. & $\begin{array}{l}\text { Firm Performance } \\
\text { Item Average }\end{array}$ & 40.36 & 0.71 & 31.67 & 5.25 \\
\hline Total of all item & 26.04 & 1.60 & 19.50 & 3.40 \\
\hline
\end{tabular}

Sumber : Data diolah, 2017

Tabel diatas menunjukkan rata-rata mean yang dihasilkan dari perusahaan adopsi ERP yaitu 26.04 sedangkan perusahaan yang tidak adopsi ERP yaitu 19.50. Dari hasil tersebut menunjukkan bahwa rata-rata mean perusahaan yang mengadopsi ERP lebih besar daripada rata-rata mean perusahaan yang tidak mengadopsi ERP. Hal ini membuktikan bahwa dengan penerapan sistem ERP meningkatkan kemampuan dalam memprediksi masa lalu, memprediksi masa depan, pelaporan keuangan dapat dilakukan dengan waktu singkat dan meningkatkan kinerja perusahaan.

Penerapan sistem ERP berpengaruh terhadap peningkatan kinerja perusahaan didukung dengan penelitian yang dilakukan Chou et, al. (2017) dengan menggunakan sistem ERP, karyawan dapat mempersingkat waktu dalam bekerja sehingga dapat membagi pengetahuan dengan karyawan yang lain sehingga pengetahuan karyawan akan bertambah luas dan meningkatkan motivasi bekerja.

Pengaruh sistem ERP terhadap nilai relevansi informasi akuntansi dan kinerja perusahaan sesuai dengan penelitian yang dilakukan oleh Matende dan Patrick (2013) yaitu sistem ERP dirancang agar mampu dalam melakukan proses informasi dalam menentukan strategi, analisis manajemen dan berfungsi dalam pengambilan keputusan.

Table II

t-test

\begin{tabular}{|r|r|r|r|r|c|}
\hline \multicolumn{5}{|c|}{ t-test table } \\
\hline No. & \multicolumn{2}{|c|}{ Description } & Mean & S.D & P-value \\
\hline 1. & Predictive Value & Adopsi & 18.56 & 1.07 & 0.00 \\
\cline { 3 - 6 } & & Non-Adopsi & 11.70 & 2.21 & \\
\hline 2. & Timeliness & Adopsi & 25.56 & 2.37 & 0.00 \\
\cline { 3 - 6 } & & Non-Adopsi & 18.53 & 4.26 & \\
\hline 3. & Feedback Value & Adopsi & 19.70 & 2.23 & 0.00 \\
& & Non-Adopsi & 16.07 & 1.89 & \\
\hline 4. & Firm Performance & Adopsi & 40.36 & 3.90 & 0.00 \\
& & Non-Adopsi & 31.67 & 5.25 & \\
\hline & & & & & \\
\hline
\end{tabular}

Sumber: Data diolah, 2017 
Mean dari predictive value menunjukkan perusahaan adopsi lebih besar dibandingkan dengan perusahaan yang tidak mengadopsi ERP dan p-value 0,00 hal ini menunjukkan bahwa p-value lebih kecil dibandingkan tingkat probabilitas 0.05 sehingga dengan kata lain $\mathrm{H}_{1}$ diterima yakni ada perbedaan antara perusahaan yang adopsi dan perusahaan yang tidak adopsi terkait dengan predictive value. Pada penelitian ini menunjukkan sistem ERP mampu menyajikan informasi-informasi masa lalu dan menyajikan informasi masa depan.

Penelitian yang dilakukan Kanellou dan Charalambos (2013) bahwa sistem ERP mempengaruhi pengguna laporan keuangan yakni salah satunya investor, investor akan menyukai laporan keuangan yang dapat memprediksi informasi masa depan dan dapat menyajikan informasi masa lalu. Galbraith (2002) penggunaan ERP secara efektif akan memiliki manfaat yang berkaitan dengan ketidakpastian biaya kegiatan, hal ini akan berpengaruh terhadap kualitas informasi bagi manajer.

Pada table II mean dari timeliness menunjukkan nilai yang lebih besar dari perusahaan adopsi yakni 25,56 dibandingkan perusahaan non adopsi ERP sebesar 18,53 p-value dari timeliness juga menunjukkan nilai dibawah tingkat probabilitas yakni 0,00 sehingga dari hasil tersebut $\mathrm{H}_{2}$ diterima. Hal ini menunjukkan bahwa penerapan sistem ERP berpengaruh signifikan terhadap ketepatan waktu dalam pelaporan keuangan sehingga informasi yang dihasilkan tidak kadaluarsa.

Hal ini sesuai dengan penelitian Trigo et, al. (2014) bahwa dengan penerapan sistem ERP mampu menjawab keresahan perusahaan dalam menyajikan laporan keuangan tepat waktu, sehingga laporan keuangan dapat memberikan informasi yang cepat, pengguna laporan keuangan juga dapat mengakses laporan keuangan dengan cepat sehingga memudahkan dalam pengambilan keputusan dan keputusan yang diambil dapat mencerminkan keadaan yng sesungguhnya.

Pengolahan laporan keuangan yang cepat dapat mengurangi biaya seperti yang dikatakan dalam penelitian Elragal dan Moutaz (2012) tanpa menggunakan sistem ERP pengolahan laporan keuangan akan dilakukan berulang kali sehingga membutuhkan biaya yang cukup besar sedangkan dengan sistem ERP laporan keuangan dapat diolah dengan waktu yang singkat sehingga biaya yang dikeluarkan dapat dikurangi. Stefanou (2002) menyatakan bahwa sistem ERP merupakan kombinasi aplikasi dan prosedur bisnis ke dalam database tunggal, sistem ini juga memberikan informasi secara real-time ke perusahaan.

Hasil yang ditunjukkan pada table II rmean dari feedback value perusahaan yang adopsi sistem ERP lebih besar 3,63 yaitu 19,70 dibandingkan dengan perusaahaan yang tidak mengadopsi ERP dan table tersebut menunjukkan nilai p-value $0,00<0,05$ sehingga $\mathrm{H}_{3}$ diterima yaitu terdapat perbedaan yang signifikan antara perusahaan yang adopsi dan perusahaan yang tidak mengadopsi ERP. Perusahaan adopsi ERP memiliki kemampuan untuk memperbaiki kesalahan yang terjadi di masa lalu.

O’Brien (2015) menayatakan bahwa sistem ERP dapat meningkatkan kualitas informasi dan dapat memperbaiki kesalahan yang terjadi namun hal ini tidak akan terjadi 
apabila sumber daya manusia atau karyawan kurang handal dalam mengoperasikan atau memiliki pengetahuan yang kurang terhadap sistem ERP.

Hasil dari kinerja perusahaan menerima $\mathrm{H}_{4}$ menunjukkan bahwa ada perbedaan yang signifikan antara perusahaan yang mengadopsi sistem ERP dan perusahaan yang tidak mengadopsi sistem hal ini dikarenakan mean dari perusaahan yang adopsi ERP jauh lebih besar dibandingkan yang tidak adopsi yakni 40,36 dan p-value menunjukkan hasil 0,00 dengan kata lain lebih kecil dibandingkan dengan probabilitas yaitu 0,05.

Penelitian yang dilakukan di Malaysia dan Indonesia oleh Fernandez, et, al. (2017) menunjukkan bahwa dengan menerapkan sistem ERP maka kinerja perusahaan akan meningkatkan efektifitas dan efisiensi kinerja perusahaan. Sehingga penelitian ini mendorong sector public untuk menerapkan sistem ERP untuk mendapatkan hasil yang lebih baik. Penelitian yang dilakukan Cotteleer dan Bendoly (2006) menyatakan bahwa sistem ERP berpengaruh signifikan terhadap kinerja perusahaan yang meliputi ketersediaan informasi, kualitas informasi, manajemen persediaan dan pengiriman yang tepat waktu.

\section{Kesimpulan}

Penelitian ini menyimpulkan bahwa adanya perbedaan yang signifikan anatara perusahaan yang adopsi sistem ERP dan tidak mengadopsi sistem ERP terkait dengan nilai relevan yang terdiri dari predictive value, timeliness, dan feedback value serta kinerja perusahaan. Sistem ERP dapat menyajikan informasi masa lalu serta masa depan sehingga perusahaan akan memiliki informasi yang lebih baik dari perusahaan yang lain dan dapat mengambil keputusan perusahaan yang lebih baik dan lebih rasional.

Sistem ERP dapat mengolah laporan keuangan dengan singkat sehingga perusahaan dapat mengambil keputusan dengan cepat hal ini dapat meminimalisir biaya serta dapat memberikan informasi yang tepat, sistem ERP juga mempengaruhi nilai umpan balik perusahaan sehingga perusahaan dapat memperbaiki kesalahan masa lalu dan dapat mengambil keputusan lebih baik sehingga akan meningkatkan kinerja perusahaan juga. Penelitian selanjutnya diharapkan dapat memperoleh data yang lebih banyak dan menambahkan beberapa variabel yang mempengaruhi implementasi ERP.

\section{DAFTAR PUSTAKA}

Albers, J. A. dan Trinidad, A.I. 2006. Knowledge Management Software: A Selection Process. CACC Journal, Reprinted from Asia-Pacific Tech Monitor, pp. 35-41.

Alcivar, Isabel dan Andres G. Abad. 2016. Design and evaluation of a gamified system for ERP training. Computers in Human Behavior 58 (2016) 109-118

Attayah, F. Osama dan Ibrahim M. Sweiti. 2014. Impact of ERP System Using on the Accounting Information Relevance: Evidence from Saudi Arabia. GSTF Journal on Business Review (GBR) Vol.3 No.2, March 2014 
Beheshti, H.M dan C.M. Beheshti. 2010. Improving Productivity and Firm Performance with Enterprise Resource Planning. Enterprise Information Systems 4(4), pp 445472.

Chand, D. Hachey, J. hunton, V. Owhoso, S. Vasudevan. 2005. A balanced scorecard based framework for assessing the strategic impacts of ERP systems. Computer Industry 56 (6) 558-572.

Chou, Huey-Wen, et, al. 2014. Knowledge sharing and ERP system usage in postimplementation stage. Computers in Human Behavior 33 (2014) 16-22

Cotteler, M. J., dan Bendoly, E. 2006. Order lead-time improvement following enterprise information technology implementation : An empirical study. MIS Quarterly, 30(3). 643-660

Dechow, N. dan Mouritsen, J. 2005. Enterprise Resource Planning Systems, Management Control and the Quest for Integration. Accounting, Organizations and Society 30(7-8), 691-733

Ehie, I. C. dan Madsen, M. 2005. Identifying Critical Issues in Enterprise Resource Planning (ERP). Computers in Industry, vol. 56, pp. 545-557

Elragal, Ahmed dan Moutaz Haddara. 2012. The Future of ERP Systems: look backward before moving forward. Procedia Technology 5 ( 2012 ) $21-30$

Ferdows, K., dan Meyer, A.D. 1990. Lasting Improvements in Manufacturing Performance : In Search of a new theory. Journal of Operations Management, 9(2), 168-183.

Fernandez, Dahlia, et al. 2017. The Impacts of ERP Systems on Public Sector Organizations. Procedia Computer Science 111 (2017) 31-36

Galbraith, J.R. 2002. Designing Organizations : An Executive Guide to Strategy, Structure and Process. New York : John Wiley and Sons Inc.

Galy, Edith dan Mary Jane Sauceda. 2014. Post-implementation practices of ERP systems and their relationship to financial performance. Information \& Management 51 (2014) 310-319

Gattiker, T. dan D. Goodhue. 2005. What Happens After ERP Implementation : Understanding the Impact of Interdependence and Differentiation on Plant-Level Outcomes. MIS Quarterly 29 (3), pp. 559-585

Hitt, L.M. dan E. Brynjolfsson. 1996. Productivity, Business Profitability and Consumer Surplus : Three Different Measures of Information Technology Value. MIS Quarterly 20 (2), pp. 121-142.

Hunton, James E., Barbara Lippincott dan Jacqueline L. Reck. 2003. Enterprise resource planning systems: comparing firm performance of adopters and nonadopters. International Journal of Accounting Information Systems 4 (2003) 165-184

Kanellou, Alexandra dan Charalambos Spathis. 2013. Accounting benefits and satisfaction in an ERP environment. International Journal of Accounting Information Systems 14 (2013) 209-234

Kieso, Weygandt dan Warfield. 2011. Intermediate Accounting. Edisi 12 Erlangga

Kocaoglu, Batuhan dan A. Zafer Acar. 2015. Developing an ERP Triggered Business Process Improvement Cycle from a Case Company. Social and Behavioral Sciences 181 ( 2015 ) $107-114$

Locke, J. dan Lowe, A. 2007. Fabrications in the Life of an ERP Package. Organization, $14,793-814$. 
Madapusi, A dan D. D'Souza. 2012. The influence of ERP system implementation on the operational performance of an organization. International Journal of Information Management 32 (2012) 24- 34

Matende, Samwel dan Patrick Ogao. 2013. Enterprise Resource Planning (ERP) System Implementation: A case for User participation. Procedia Technology 9 ( 2013 ) $518-526$

May, Jeffrey, et al. 2013. Defining value-based objectives for ERP systems planning. Decision Support Systems 55 (2013) 98-109

O'Brien, Tony. 2015. Accounting' for data quality in enterprise systems. Procedia Computer Science 64 ( 2015 ) 442 - 449

Scott, J dan I. Vessey. 2000. Implementing Enterprise Resource Planning Systems : the Role of Learning from Failure. Information Systems Frontiers 2 (2) pp. 213-232

Sevenpri, Candra. 2012. ERP Implementation Success and Knowledge Capability. Procedia - Social and Behavioral Sciences 65 ( 2012 ) 141 - 149

Shen, Yung-Chi, et al. 2015. A Study of Enterprise Resource Planning (ERP) System Performance Measurement Using the Quantitative Balanced Scorecard Approach. Computers in Industry 75 (2016) 127-139

Stefanou, J. C. 2002. Accounting Information Systems (AIS) Development/ Acquisition Approaches by Greek SME. In European Conference on Accounting Information Systems (ECAIS), Copenhagen, Denmark.

Trigo, António, et, al. 2014. Accounting Information Systems: The Challenge of the RealTime Reporting. Procedia Technology 16 ( 2014 ) 118 - 127 